УДК 069.1: 172.15(470.630)

\title{
ОСОБЕННОСТИ ЭКСПОЗИЦИОННО-ВЫСТАВОЧНОЙ РАБОТЫ МУЗЕЕВ
} СТАВРОПОЛЬЯ В СОВЕТСКИЙ ПЕРИОД

Статья посвящена малоизученному вопросу в области истории музейного дела на Ставрополье - изменению подходов к содержанию музейных экспозиций и выставок в советский период. В статье на основе анализа документов из фондов Государственного архива Российской Федерации, Государственного архива Ставропольского края, Ставропольского государственного историко-культурного и природно-ландшафтного музея-заповедника им. Г. Н. Прозрителева и Г. К. Праве показаны изменения направления экспозиционно-выставочной работы - от просветительской на начальном этапе, к агитационно-пропагандистской и юбилейной к концу рассматриваемого периода. Приводится тематика выставок, организуемых ставропольскими музеями, как пример их разнонаправленной просветительской работы. Выявлено влияние и жесткий контроль руководящих органов в определении тематики и содержания экспозиций. Проанализирована деятельность по организации передвижных выставок в рамках проводимой музеями края массово-политической работы с сельским населением. Впервые приводятся факты о вагоне-музее как новой форме работы Ставропольского краевого краеведческого музея. На основе приведенной информации можно сделать вывод, что большинство музейных выставок на Ставрополье в 1920-е гг. носили просветительный характер, в первую очередь по наиболее актуальным социальным вопросам - борьбы с инфекционными болезнями, алкоголизмом, ухода за детьми и т.П. С 1930-х гг. происходит изменение содержания экспозиций с доминированием в нем политического просвещения. Великая Отечественная война подняла тематику героической борьбы русского народа с завоевателями. На местном уровне усиление патриотической направленности в выставочной работе проявилось наиболее ярко в создании раздела экспозиции «Лермонтов-патриот» в лермонтовском музее. В первые послевоенные годы экспозиционно-выставочная работа музеев фиксировала злодеяния немецко-фашистских захватчиков в период оккупации, успехи в восстановлении промышленности и сельского хозяйства края. С середины 1950-х гг. наибольшее распространение получили выставки, рассказывающие об успехах в экономике края. Большое количество выставок, устраиваемых музеями края начиная с 1970-х гг., было посвящено юбилейным датам. В период перестройки в выставочной деятельности наблюдается отход от жестких идеологических установок, большое внимание начинает уделяться региональным особенностям края, в частности, появляются материалы о казачестве.

Ключевые слова: музей, экскурсия, выставка, экспозиция, вагон-музей, пропаганда, Ставрополье.

\section{S. M. Duginets}

\section{THE FEATURES OF EXPOSITION AND EXHIBITION WORK OF STAVROPOL KRAI MUSEUMS IN THE SOVIET PERIOD}

The article is devoted to the little-studied issue in the history of museum business in Stavropol - changing approaches to the content of museum expositions and exhibitions during the Soviet period. The article is based on the analysis of documents from the state archive of the Russian Federation, the State archive of the Stavropol Krai, the Stavropol state historical, cultural and natural landscape Museum-reserve named after G. N. Prozriteleva and G. K. Prave. The study shows the changes in the direction of exhibition work - from educational at the initial stage, to propaganda and anniversary by the end of the period under review. The subject of exhibitions organized by Stavropol museums is given as an example of their multidirectional educational work. The influence and strict control of the governing bodies in determining the subject and content of expositions are revealed. The activity on the organization of traveling exhibitions within the framework of mass-political work with the rural population carried out by museums of the region is analyzed. For the first time the facts about the museum car as a new form of work of the Stavropol regional Museum are given. Based on this information, we can conclude that most of the Museum exhibitions in the Stavropol region in the 1920 s were educational by nature, primarily on the most pressing social issues - the fight against infectious diseases, alcoholism, childcare, etc. Since the 1930s, there is a change in the content of expositions with the dominance of political education. The great Patriotic war raised the theme of the heroic struggle of the Russian people with the invaders. At the local level, the strengthening of Patriotic orientation in the exhibition work was manifested most clearly in the creation of the section of the exhibition "Lermontov-the patriot" in the Lermontov Museum. In the first postwar years, the exhibition work of museums recorded the atrocities of the Nazi invaders during the occupation, the success in the restoration of industry and agriculture of the region. Since the mid-1950s, the most widespread exhibitions featured the success in the economy of the region. A large number of exhibitions organized by museums of the region since the 1970 s, was devoted to anniversaries. During perestroika the exhibition activity breaks away from rigid ideological guidelines, much attention begins is paid to regional features, in particular, there are materials about the Cossacks.

Key words: museum, excursion, exhibition, exposition, museum car, propaganda, Stavropol. 
Музеи на протяжении своей истории призваны быть центрами сохранения и передачи социально значимой культурной информации последующим поколениям. Необходимость всестороннего изучения деятельности музея является актуальной темой исследования. Одной из малоизученных тем стала деятельность музеев по отражению требований государства. Вопросы содержания государственной политики в отношении музеев в различные периоды и этапы становления и развития музейного дела в России были рассмотрены в первом томе «Государственная политика в области музейного дела (XVIII-XX вв.)» сборника коллектива авторов «Музей и власть» в двух томах [30].

Ставропольские ученые также занимались исследованиями по данной проблематике. Роль музея в жизни многонационального региона в начале $X X$ в. проанализирована в работе Е. П. Поповой [31]. К 1990-м гг. относится и начало научных исследований М.Е. Колесниковой в сорере региональной историко-краеведческой и музейной деятельности, которые продолжились и в 2000-е пт. [26, 27].

Политико-массовой и культурной жизни в Ставропольском крае в 1945-1964 гг. посвящено диссертационное исследование Л. П. Сафроновой. Музеи в данной работе считаются неотъемлемой частью культурно-просветительной работы, но их деятельность подробно не освещается и не анализируется [32]. В диссертационном исследовании М. А. Лукаша музеи рассматриваются как одно из учреждений культуры, выполняющее свои функции в рамках реализации молодежной политики государства [29].

Работа музеев в условиях идеологического контроля хорошо описана в мемуарах В. В. Госданкера $[23,24]$. Большое количество информации o проводимых в музеях края мероприятиях открытиях выставок, чтения лекций - представлено в региональных газетах.

Проведенный историографический обзор дает основание говорить о том, что, несмотря на имеющиеся работы, раскрывающие отдельные моменты рассматриваемой темы, все они носят локальный и фррагментарный характер, на длительном промежутке времени исследование данной проблемы не проводилось. Исходя из этого, целью настоящего исследования является выявление характера изменений в подходах к экспозиционно-выставочной работе, проводимой музеями края на протяжении всего советского периода.

В 1920-е гг., в связи с изменившимися социополитическими условиями в России, поменялась и роль музеев. Его главной задачей стала пропаганда достижений советского государства при помощи всех направлений музейной деятельности. Постепенно это стало признаваться в качестве ведущей социальной функции любого музея страны, независимо от его профиля. Деятельность ставропольских музеев соответствовала этим требованиям.

После окончательного установления советской власти в регионе, Ставропольский музей им. М. В. Праве в 1920 гг. целью своей работы обозначил просвещение трудящихся масс губернии путем устройства постоянных и передвижных выставок по всем отраслям знаний и, особенно по тем, которые ближе обслуживали потребности текущего момента (сельского хозяйства, по борьбе с заразными болезнями, по уходу за малыми детьми). За период с 1 октября 1922 по 1 октября 1923 гт. в музее были организованы 4 крупные выставки: «Мелкое животноводство, севооборот, возделывание картофеля, сахарной свеклы и по кооперации»; «По вредным инфекциям - дизентерии, холере, брюшному тифу»; «Памяти Л. Н. Толстого»; «По социальным болезням (алкоголизму, венерическим болезням, туберкулезу)", а также 5 выставок на актуальные темы в Т.ч. по борьбе с мышами и саранчой, по очистке семян [5, л. 3]. В 1925-1926 гг. музей устроил 7 выставок: «Пчеловодство и шелководство», «Туберкулез и борьба с ним», «Растения и что из них добывают», «Кустарно-заводское производство», «История письмен и книгопечатания», «Женщина и охрана материнства», “Сельское хозяйство».

Не менее активную просветительную работу проводил Музей Северного Кавказа в г. Ставрополе. Учитывая аграрную направленность экономики региона, в 1920-е гг. Г. Н. Прозрителев читал лекции слушателям совпартшколы, красноармейцам кавалерийской дивизии по сельскому хозяйству и ветеринарии. Рассказы Г Н. Прозрителева были востребованы людыми, газеты регулярно публиковали объявления о предстоящих лекциях с анонсом тем, а сам Григорий Николаевич стал авторитетом для простых людей в различных вопросах сельского хозяйства. Именно ему крестьяне писали письма с просьбой дать совет: какая сеялка лучше, у кого лучше приобрести семена, какие сорта плодовых деревьев сажать в супесчаную почву [20, л. 19].

Руководящие органы определяли задачи музеев в это время следующим образом: интенсивное участие в научно-исследовательской работе страны, обслуживание населения в просветительном отношении, содействие выявлению естественных производительных сил страны и развитию народного хозяйства, содействие хозяйственному и культурному росту национальных меньшинств, делу подготовки защитников социалистического Отечества и других задач государственного строительства. Целью деятельности краеведческих музеев, стало «показать, каковы очередные нужды края, каковы его больные места, какая работа ведется и как, что надо сделать в дальнейшем и какими средствами располагает край для исполнения предложенных работ».

С конца 1920-х гг. перспективы развития культуры стали определяться пятилетними народнохозяйственными планами. Музеи были нацелены на участие в важнейших задачах социалистического строительства и стали приближены запросам школьного и профтехнического образования и массового просвещения. Также музеи принимали активное участие в проведении различных агитационных и политических кампаний (по поднятию урожайности, предвыборные, антирели- 
гиозные и др.). Для этих целей использовались внемузейные фрормы - лекции и передвижные выставки, построенные на общем иллюстративном материале, не связанном со спецификой края («Сталинская конституция», «Женщина в СССР», «Молодежь в нашей стране» и т.п.).

В ставропольских музеях в 1930-е гг. важная роль отводилась выставкам, рассказывающим о первых ростках возрождения отечественного производства. В Ставропольском краеведческом музее были представлены новые коллекции, демонстрирующие продукцию производства - образцы подсолнечного масла, костяных пуговиц, шерсти, чугуна, муки, гвоздей и др. Всего за 1930 год музей организовал 13 выставок на самые разнообразные темы, в числе которых были «Глаз и его болезни» и "Северные окраины СССР». Демонстрировались выставки на консервном, кожевенном и маслозаводе, мясокомбинате, биофабрике, заводе «Красный металлист», в клубе колхозников [33, л. 5, 9]. Пятигорский краеведческий музей в 1931 гг. в степи колхоза «Красный партизан» развернул выставку-передвижку «Вредители сельского хозяйства и борьба с ними". Также сотрудники музея выезжали в цыганский колхоз «Труд Ромэн» (вблизи Минеральных Вод).

Несмотря на то, что “Домик Лермонтова» являлся мемориальным музеем, в 1930-е гг. в выставочной работе политическая проблематика также находила свое отражение. Во 2-й пятилетке музей взял на себя обязательство построить постоянно действующую выставку, отражающую борьбу народа с помещиками и капиталистами, негативную роль церкви, крестьянские бунты и их подавление, завоевательную политику царизма $[28$, c. 4].

Руководящие органы следили за тем, чтобы тематика выставочной работы музеев соответствовала актуальным запросам общества. В 1936 гг Северо-Кавказский краевой отдел народного образования разослал директорам музеев края темы выставок-передвижек по обслуживанию весенне-посевной кампании музеями края: «Борьба за сохранность урожая (борьба с сорняками и вредителями сельского хозяйства)», «История развития человеческого общества (археологические материалы)», «Природные богатства Северо-Кавказского края (полезные ископаемые)", «Курорты до и после революции», «Почему мы боремся с религией», «Роль С. М. Кирова и Орджоникидзе в советизации Северо-Кавказского края» $[10$, л. 164].

В методическом письме музейно-краеведческого отдела Наркомпроса «Об использовании опыта экспозиции ВСХВ» (1939 г.) говорилось о том, что музеи должны использовать опыт Всесоюзной сельскохозяйственной выставки, являющейся «выдающимся историческим событием в жизни СССР». В соответствии с этим письмом в ноябре 1939 г. заведующему отделом соцстроительства Ставропольского музея Рутберг было поручено проработать план выставки достижений в сельском хозяйстве края, в которой основной упор должен быть взят на показ кандидатов на ВСХВ, передовиков колхозов, совхозов, МТС. К концу 1930-х гг. в краевом музее были созданы панорама завода «Красный металлист», макеты лучшего колхоза и совхоза. Важным событием в жизни музея стало открытие выставки «Невинномысский канал - народная стройка» [2, с. 53].

Война полставила перед музеями две главные задачи: сохранить музейные ценности и определить основные формы своей деятельности в новых экстремальных условиях. Именгно на эти задачи, как на важнейшие для данного времени, указывалось в приказах Наркомпроса РСФСР 1941 г. «О мероприятиях по сохранению и учету музейных фондов в годы войны» и «О формах функционирования музеев в условиях военного времени" [22, с. 187]. На начальном этапе Великой Отечественной войны соответствовать тенденции пропаганды успехов было проблематично: в связи с отступлением советских войск показ хода войны в музее был невозможен. В деятельности музеев распространение получили выставки на историческую тематику - борьба русского народа с немецкими интервентами под руководством Александра Невского, суворовские походы, героическая оборона Севастополя, знаменитый прорыв Брусилова, героическая борьба советского народа в период Гражданской войны, успехи в советско-фринской войне [35, с. 207]

Обстановке военного времени соответствовала выставка Ставропольского краевого музея «Героическое прошлое русского народа и народов СССР». В этот период все выставки музея носили патриотическую направленность - за 2 месяца после начала войны их было организовано 16. Даже отдел природы строил свою работу с учетом потребностей военного времени - его выставки имели военно-оборонное значение (природные ископаемые, пекарственное сырье). У входа в музей организована витрина со свежими сводками ТАСС и другими материалами, которые обновлялись ежедневно. Пятигорский краеведческий музей организовал выставки на оборонные темы - о событиях войны 1812 г., о борьбе Красной Армии с интервенцией, о текущих событиях Великой Отечественной войны. С началом войны музей «Домик Лермонтова» также ставил своей задачей усиление агитационно-массовой работы. Особой задачей литературного музея было научить по его произведениям «еще больше любить свою родину и самоотверженно защищать ее от вандализма германского фашизма» [13, л. 1]. В экспозиции музея появились отделы «Бородино» и «Лермонтов - патриот».

После освобождения Ставрополя от немецко-фрашистских захватчиков, уже в марте 1943 г в краевом музее была организована выставка «Наши великие предки. Героическое прошлое русского народа», рассказывающая о борьбе против монголо-татарского ига, немецких рыцарей польских интервентов, шведских захватчиков, об Отечественной войне 1812 г. и борьбе советского народа против иностранных интервентов, и контрреволюции. Вскоре была открыта выставка «Пять месяцев фашистской оккупации в Став- 
ропольском крае», рассказывающая о зверствах немецко-фашистских оккупантов, о партизанском движении в тылу врага [4, л.3-4].

Пятигорский, Черкесский, Карачаевский краеведческие музеи организовывали выставки «Зверства и разрушения, произведенные фашистскими бандитами в период оккупации $[11, \pi .62-$ $66 ; 12, \pi .29]$

В 1946 г. основным руководящим документом в деле восстановления и развития музеев стал Закон «О пятилетнем плане восстановления и развития народного хозяйства СССР». Музеи Ставрополья живо откликнулись на его принятие. Уже к маю 1946 г. только Ставропольский краевой музей изготовил 16 выставок в музее и выставок-передвижек на темы о 5-летнем плане. Для колхозов были созданы передвижные выставки по темам «Задачи сельского хозяйства края в послевоенной пятилетке», «Новая техника на колхозных полях», «Кубань-Егорлыкская оросительная система» [6, л. 1]. Ставрополье было показано как крупнейшая житница страны и огромная база животноводства. Аналогичные выставки устраивали все музеи края.

Тематика музейных выставок тех лет продолжала оставаться разнообразной: из истории Гражданской войны на Ставрополье, Герои Социалистического Труда - ставропольцы, происхождение человека и общества, происхождение жизни на земле, природа Ставрополья, природные богатства Ставрополья и их использование, мичуринское учение - основа научной биологии, женщина в СССР, пятилетний план восстания и развития народного хозяйства, Нюрнбергский процесс, Парад Победы. За 1948 г. по музеям края было организовано 105 выставок [17, л. 87-88].

«Идеологическая правильность» содержания экспозиций определялась наличием в ней фотографий и цитат В. И. Ленина, И. В. Сталина и других деятелей коммунистической партии и Советского государства. Именно этим объясняется наличие такого материала в открытом в 1954 г. отделе музея «Лермонтов и наша современность».

Диктатура в духовно-идеологической сфере перекликалась с диктатурой в области науки. На сессии Всесоюзной академии сельскохозяйственных наук им. В. И. Ленина по вопросам о положении в биологической науке в августе 1948 г. работы ученых-генетиков были объявлены лжеучеными, а их труды - вне закона. В соответствии с решениями сессии краеведческие музеи вынуждены были вносить изменения в экспозиции отделов природы В 1949 г отдел природы Пятигорского краеведческого музея пополнился новыми экспозиционными комплексами - «Мичуринское учение - основа современной биологии» и «Климат и почва района KMB». Большое внимание в своей работе уделял краевой музей пропаганде Сталинского плана преобразования природы [21, с. 28].

Диктат руководящих органов проявлялся также в том, что даже в материалах выставки краевого музея «Ставропольский край - край высокой механизации сельскохозяйственного производства» и «Озимая пшеница - основная высокоурожай- ная зерновая культура в Ставропольском крае» цензором Краевого управления по делам литературы и издательств (Крайлит) были найдены сведения, запрещенные к открытому обозрению. Экспонаты изъяты до соответствующего исправления и просмотра комиссией, а выставки временно запрещены. Директор музея Г. Д. Краснов был предупрежден под расписку об ответственности за сохранение военных и государственных тайн в экспозиции музея [7, л. 1].

Руководящие органы считали, что большую познавательную ценность для посетителей краеведческого музея представляли материалы, характеризующие технический прогресс в развитии сельскохозяйственного производства. В 1950-е гг. в музеи Ставрополья поступали дары от краевого управления сельского хозяйства. В пополнении фондов принимали участие и вузы края. Сотрудники Ставропольского сельскохозяйственного института подарили краевому музею многолетнюю рожь и сорго-гуманиевый гибрид. Пятигорский музей развитие советской промышленности и техники представил экспонированием макета колхозной гидроэлектростанции. Коллектив ремонтного завода сделал и подарил музею макет шагающего экскаватора в 1/20 натуральной величины машины [1, с. 91].

Удивительно, что вопросы экономического развития региона, благодаря позиции партии, удавалось освещать даже в лермонтовском музее. На литературном вечере, проходившем в 1953 г, известный лермонтовед В. А. Мануйлов прочел лекцию «Задачи советского литературоведения в свете решений XIX съезда партии и гениальных трудов товарища Сталина «Экономические способы социализма в России». Лектор критиковал работников музея за то, что, несмотря на достигнутые результаты в исследовательской работе, ими не созданы работы по творчеству Лермонтова

В 1956 г., после известного доклада Н. С. Хрущева, все учреждения культуры страны включились в работу по преодолению культа личности Сталина. Не остались в стороне и ставропольские музеи. Проходило списание экспонатов, связанных с периодом культа личности, грубо фальсифицирующих историю. В Ставропольском краевом музее из основного фонда в научно-вспомогательный были переведены 1790 единиц хранения. Из экспозиции музея извлекались экспонаты, связанные с личностью И. В. Сталина. Работники музея вспоминают, что медали с изображением Сталина переворачивали на другую сторону

По-прежнему в экспозициях отделов истории советского общества краеведческих музеев широко пропагандировались достижения местной промышленности и сельского хозяйства. Краевой музей совместно со Ставропольским совнархозом в экспозиции установили ряд ценных экспонатов химической промышленности, в т.ч. макет Невинномысского азотно-тукового комбината, токарные станки завода «Красный металлист» и др. Для показа роли природного ставропольского газа в народном хозяйстве страны в 1958 г. работниками музея подготовлена большая электрифи- 
цированная карта газопровода «Ставрополь-Москва-Ленинград». Отдел промышленности края пополнился большим количеством новых экспонатов, показывающих Ставропольский сажевый завод, Георгиевский арматурный, Ставропольский завод поршневых колец, горнорудную промышленность КЧАО и других предприятий края. После того, как в Левокумском районе, впервые на Ставрополье, начали выводить нутрий, директор краевого музея Г. Д. Краснов выступил с инициативой пропаганды их разведения в районах края $[15$, л. 117].

В силу аграрной специфики региона, крайком КПСС делал упор на культурное обслуживание работников колхозов и совхозов, механизаторских бригад. Пропаганде сельскохозяйственных знаний в музеях и работе с сельским населением уделялось особое внимание. Так, в 1951 г Ставропольским краевым музеем из 66 выставок 27 были организованы по сельскому хозяйству, в Черкесском - 8 из 23, в Пятигорском - 1 из 4. Но, несмотря на это, на заседании Ставропольского крайисполкома 13 ноября 1951 г., был заслушан доклад директора Ставропольского краевого музея Г Д. Краснова. Исполком отметил слабую работу музея в деле пропаганды передовых методов соцстроительства. Учитывая вышеизложенное, исполком крайсовета постановил улучшить работу музея, направив главное внимание на пропаганду научных знаний и передовых методов соцстроительства путем организации показа достижений передовых колхозов, совхозов края, героев Социалистического Труда. На следующий год работа с сельским населением проводилась гораздо активнее. В период весеннего сева в колхозы выезжали три сотрудника краевого музея, которые пробыли в общей сложности 2 месяца. Черкесский областной музей в период весенне-посевной кампании музей принимал участие в культурно-массовой работе в поле, провел 351 беседу в колхозах области по различной тематике.

С началом освоения целинных и залежных земель в 1954 г. музеи включились в популяризацию достижений советской молодежи. В Пятигорском музее была открыта стенд-выставка комплекса «На распашку целинных и залежных земель».

Ставропольский крайком КПСС 16 сентября 1957 г. заслушал вопрос «О массово-политической работе и культурном обслуживании чабанских бригад на отгонных пастбищах в период зимовки 1957-1958 годов». Была отмечена неудовлетворительная работа в культурном обслуживании животноводов, т.К. работники краевого управления культуры редко бывали на отгонных пастбищах, слабо направляли деятельность краевых учреждений культуры на улучшение их работы по обслуживанию чабанских бригад, плохо обобщали и распространяли опыт лучших по работе среди чабанов на Черных землях. Поэтому был предложен план, в котором были предусмотрены показ на отгонных пастбищах передвижных выставок по темам: “Ставрополье за 40 лет», «Историко-революционные памятники на Ставрополье» $[3$, л. 7].
С целью приобщения сельских жителей к культурным ценностям в 1962 г. в краевом музее появилась новая форма массово-политической работы - деятельность вагона-музея, экспозиция которого раскрывала основные черты природы, экономики и истории края. В течение 45 дней в мае-июне по железнодорожным веткам Ставрополь-Кавказская, Ставрополь-Дивное-Петровское-Благодарное курсировал агитпоезд, состоящий из вагона-клуба (с киноустановкой) и вагона-музея. На каждой станции вагон-музей стоял не более суток. В вагоне вмещалась до 20 человек, что приводило к ограничению посещаемости и приходилось работать с 7 до 22 часов [34, л. 1417]. Желающих посетить вагон-музей было очень много, поэтому члены агитбригады выходили с экспонатами в железнодорожные клубы, школы, фермы, а порой и на пристанционные лужайки. За время своей работы вагон-музей посетил 27 станций и полустанков, сотрудники провели 314 экскурсий и бесед для 30 тысяч жителей отдаленных населенных пунктов. Опыт Ставропольского музея перенял республиканский музей Татарской АССР, организовав пароход-музей, курсировавший по Волге [23, л. 155]

Дальнейшее влияние на деятельность музеев оказало постановление ЦК КПСС от 9 января 1960 г. «О задачах партий-ной пропаганды в современных условиях", согласно которому все средства пропаганды должны были раскрывать преимущества социализма, выдающиеся достижения во всех областях общественной жизни в целях воспитания советских людей в духе советского патриотизма и национальной гордости. В документах того времени, на съездах и пленумах партии говорилось о том, что именно культурно-просветительные учреждения должны стать центрами агитационно-пропагандистской работы и своими специфическими приемами умело и доходчиво пропагандировать коммунистическую идеологию, помогая воспитанию нового человека $[25$, c.23]. Перед музеями стояли задачи широкой пропаганды материалов съездов КПСС; искоренение ошибок, связанных с периодом культа личности; расширение политической и массово-просветительной работы в сельской местности; ввод новых экспозиций, отражающих достижения советского строя.

В мае 1964 г. ЦК КПСС принял постановление «О повышении роли музеев в коммунистическом воспитании трудящихся». В нем выдвигались задачи организации во всех музеях отделов по советскому периоду с раскрытием успехов социалистического строительства и укрепления связи музеев с промышленными и сельскохозяйственными предприятиями, учебными заведениями, научными и творческими обществами. В августе 1964 г. состоялось заседание Идеологической комиссии Ставропольского крайкома КПСС и Бюро крайкома КПСС по вопросу «О состоянии и мерах улучшения работы музеев края». Был разработан план мероприятий по устранению недостатков в Ставропольском краевом музее. В плане было предусмотрено: введение дополнительных ком- 
плексов в экспозицию «Ставрополье в период завершения строительства социализма 19531958 г.», «Ставрополье в период развернутого строительства коммунизма. Выполнение 7-летнего плана 1959-1965 гг.»; усиление тематически и иллюстративно комплексов, посвященных съездам КПСС; изучение, сбор материала по наиболее важным моментам истории края: «Укрупнение колхозов края», «Инициатива ставропольцев в переходе на хозрасчет в колхозных бригадах ежемесячное авансирование колхозников» и др.; установление связей с колхозами, совхозами, СНИИСХ, ВНИИОК, с предприятиями, организациями здравоохранения, просвещения, науки, искусства, из крайкома ВЛКСМ (история комсомола), материалами Съездов и Пленумов ЦК КПСС. Данный план отражал основные тенденции в развитии музеев и был полностью выполнен в 19651966 гг. [8, л.1-8].

В рамках культурного обслуживания сельских жителей учреждениями культуры по заранее составленному плану проводилось чтение лекций бесед, организовывались выставки-передвижки и показ кинофильмов. Темы выступлений сотрудников музеев в 1976 г. перед жителями села были очень разнообразны: «Ставрополье навстречу XXV съезду КПСС», «К 150-летию восстания декабристов», «Из истории народной медицины Карачая» и др. Многообразие наблюдалось и в тематике передвижных выставок - о природе, Великой Отечественной войне, о Л. Н. Толстом, страницы истории партийной организации Ставрополья, к 150-летию восстания декабристов, к 70-летию Брежнева, край в X пятилетке, «Учение Дарвина» $[9$, л. 17].

Шефские связи с тружениками полей Ставрополья были у музея “Домик Лермонтова». Его сотрудники часто выезжали в районы края с докладами, посвященными жизни и творчеству поэта, сопровождая их небольшими выставками, лекциями на темы «Черты живые Ильича», «В. И. Ленин и литература» $[14$, л. 1]. С 1970 г в музее появилась новая форма работы - день открытых дверей для работников сельского хозяйства. В 1973 г. музей открыл большую передвижную выставку «Жизнь и творчество М. Ю. Лермонтова», предназначенную для демонстрации в сельских районах

Работу с сельским населением проводили и художественные музеи. Претворяя решения XXIV съезда в области культурного строительства на селе, приобщения сельских тружеников к художественным ценностям в жизнь, краевой музей изобразительных искусств скоординировал выставочную деятельность со Ставропольской организацией сельского хозяйства. В 1970-е гг музей регулярно проводил «Неделю изобразительного искусства на селе», выставки в районах края. Большим недостатком этих выставок было то, что они были однодневными. Также музей организовывал «Дни изобразительного искусства» - выставки, экскурсии, лекции, беседы, консультации в домах культуры районов края. Часто выезды музея в сельские районы приурочивались к ежегодному месячнику «Город - селу» [16, л. 10] Музей Ярошенко организовал в подшефном Арзгирском районе филиал музея, а при нем постоянную работу факультета изобразительных искусств. Занятия проходили в форме лекций, бесед научных сотрудников музея. Регулярно устраивались выставки-передвижки и экскурсии слушателей университета в музей.

В 1970-1980-е гг. местные партийные органы старались усилить свое влияние на социально-культурную жизнь края, обеспечить рост культурного уровня населения. Опираясь на разветвленную сеть культурно-просветительных учреждений, которые действовали на всех крупных предприятиях, в каждом населенном пункте, и, используя возможности СМИ, партийные, советские и общественные организации поднимали уровень воспитательной работы в трудовых коллективах, культуры, общественную активность трудящихся края. Вся работа музеев разворачивалась в соответствии с решениями съездов КПСС в области идеологической работы. Деятельность музеев была направлена на организацию и проведение общественно-политических и музейных мероприятий к знаменательным датам и событиям к юбилеям выдающихся политических деятелей, выборам в Верховный Совет и местные Советы народных депутатов, Дню Мира, Дню учителя, Дню знаний, Дню города, Международного дня музеев. Отделам истории советского общества, как и в прежние годы, отводилась ведущая роль.

В 1972 г. состоялось совещание Всероссийских работников культуры и искусства, посвященное задачам органов и учреждений культуры и искусства по выполнению решений XXIV съезда партии. В своем докладе министр культуры Н. А. Кузнецов в качестве главной задачи поставил такую, чтобы все музеи, независимо от их профиля, от исторического периода, более активно работали на современность, активно пропагандировали достижения советской родины и коммунистической партии $[18$, л. 1-50].

В период перестройки началось переосмысление роли и места учреждений, нацеленных на сохранение социальной памяти - библиотек, архивов, музеев. В целях эффективного сочетания новых методов хозяйствования и прогрессивных организационных структур и в соответствии с Постановлением ЦК КПСС и Совета Министров СССР от 8 июля 1988 г. №824 «О генеральной схеме управления народным хозяйством РСФСР» была введена в действие генеральная схема управления, предусматривающая развитие, исходя из местных условий, сети музеев $[19, \pi .76]$.

Сотрудники музеев с подъемом встретили перестройку, демократизацию духовной жизни. Для них открывался доступ к архивным пластам, ранее запрещенной литературе, свободе слова и мнений. Музеи постепенно стали отходить от догм социализма. Сотрудники начали модернизировать экспозиции, особенно по истории советского общества. В этот период раскрылись просторы для новой интерпретации экспозиций и выставок по военной и революционной темам. 
Цензоры перестали жестко контролировать содержание музейных экспозиций и выставок. В 1987 г., к 70-летию Октябрьской революции, поместили в экспозицию портреты представителей белого движения - П. Н. Врангеля и А. Г Шкуро. Но “оргвыводов» со стороны властей не последовало.

Обращение к национальному самосознанию и исторической памяти стало одним из источников возрождения казачества. В конце 1980-х годов по инициативе самих казаков начался процесс возрождения казачества. В этот же период органы власти начали уделять внимание реабилитации репрессированного российского казачества. Музеи региона не остались в стороне от происходящих перемен. В Ставропольском музее в результате экспедиционной работы стала формироваться коллекция по истории и быту казачества. В основную экспозицию музея был введен раздел о казаках, в котором представлены их одежда и предметы быта.

При формировании экспозиций в музее основное внимание стало уделяться нравственному воспитанию, раскрытию духовного и творческого потенциала россиян, формированию национального самосознания. В то же время музейная экспозиция продолжала оставаться средством пропаганды. Основная тематика музейных выставок в 1980-е гг. была следующая: «Мы мирные люди», «Мир на Знамени Октября», «Ставрополь-Пазарджик - города-братья», «Ставрополье в годы Великой Отечественной войны», «За нашу Советскую Родину (Великая Отечественная война в плакатах и литографриях)», «Активные участники установления советской власти и Гражданской войны на Ставрополье», «Герои Советского Союза и кавалеры 3-х орденов Славы - активные борцы за мир», «Фронтовые письма», «Памятники истории и культуры Ставропольского края», «Традиции 1-й Конной армии продолжаются», «Наш дом - Земля», «Памятники природы Ставропольского края», «По страницам Красной Книги», «История здравоохранения Ставрополья».

Для музейного дела эпохи «перестройки» характерен кризис в экспозиционной деятельности музеев страны, особенно музеев исторического профиля. Музейная «модель мира», направленная на "отражение развитого социализма", вошла в серьезное противоречие $c$ реальной жизнью. Именно с этим многие связывают уменьшение числа посетителей исторических и краеведческих музеев страны, наблюдающиеся в конце 1980-х Гг.
Подводя итог, следует отметить, что в 1920-е гг большинство музейных выставок на Ставрополье носили просветительный характер, в частности, после окончательного установления советской власти Ставропольский музей им. М.В.Праве обозначил просвещение трудящихся масс губернии своей приоритетной задачей. Это касалось в первую очередь наиболее актуальных социальных вопросов - борьбы с инфекционными болезнями, алкоголизмом, ухода за детьми, борьбы с сельскохозяйственными вредителями и т.п. С 1930-х гг содержание выставок и экспозиций начинает меняться: отчетливо проявляется идеологическая составляющая, в работе музеев доминирует политическое просвещение. С началом Великой Отечественной войны в музеях края поднимается тема героической борьбы русского народа с завоевателями: выставки посвящаются победоносным сражениям и выдающимся полководцам. На местном уровне усиление патриотической направленности в выставочной работе проявилось, например, в создании в лермонтовском музее раздела экспозиции «Лермонтов-патриот». В первые послевоенные годы экспозиционно-выставочная работа музеев отражала злодеяния немецко-фрашистских захватчиков, успехи в восстановлении промышленности и сельского хозяйства края. В конце 1940-х гг. в экспозиционно-выставочной работе возникла тема Сталинского плана преобразования природы, которая после смерти вождя утрачивает свою актуальность. С развенчанием культа личности Сталина из экспозиций изымались предметы с его изображением и цитатами. С середины 1950-х гг. наибольшее распространение получили выставки, рассказывающие об успехах в экономике края, об участии ставропольчан в освоении целинных и залежных земель. В 1960-1970-е гг активно разворачивалась работа с сельским населением, местным изобретением стала передвижная выставка на базе вагона-музея. Большое количество выставок, устраиваемых музеями края в 1970-е гт., было посвящено юбилейным датам - к 150-летию восстания декабристов, к 70-летию Л. И. Брежнева и т.п. Такая направленность музейной деятельности сохранялась до середины 1980-х гг., когда в период перестройки наметились тенденции отхода от жестких идеологических установок. Отдельное внимание в экспозиционно-выставочной работе начинает уделяться региональным особенностям края, в частности, появляются материалы о казаках.

\section{Источники и литература}

1. Багдасарян А. А. Летопись Пятигорского краеведческого музея (1847-2005). Пятигорск: Вестник Кавказа, 2007. 202 с., ил.

2. Булыгина Т. А. Музейная экспозиция как источник интеллектуальной истории локального сообщества (на примере СГМЗ им. Г. Н. Прозрителева и Г. К. Праве) // Прозрителевские чтения: сборник материалов научно-практической конференции. Вып. 2 (научное издание) / под ред. С. Н. Савенко. Ставрополь: Вестник Кавказа, 2006. С. $52-55$

3. Государственный архив новейшей истории Ставропольского края (далее - ГАНИСК). Ф.1. Оп.43. Д. 2708.

4. ГАНИСК. Ф.1. ОП.2. Д.580.

5. Государственный архив Ставропольского края (далее - ГАСК). Ф.Р-164. Оп.1. Д.484

6. ГАСК. Ф.Р-645. ОП.3. Д.27. 
7. ГАСК. Ф.Р-645. ОП.З. Д.112.

8. ГАСК. Ф.Р-645. ОП.3. Д.221

9. ГАСК. Ф.Р-645. ОП.3. Д.394

10. ГАСК. Ф.Р-1077. ОП.1. Д.33

11. ГАСК. Ф.Р-2174. Оп.1. Д.38.

12. ГАСК. Ф.Р-2928. ОП.1. Д.10

13. ГАСК. Ф.Р-3020. ОП.1. Д.37.

14. ГАСК. Ф.Р-3020. ОП.1. Д.360

15. ГАСК. Ф.Р-3798. ОП.1. Д.221

16. ГАСК. Ф.Р-4210. Оп.1. Д.206.

17. Государственный архив Российской Федерации (далее - ГАРФ). Ф.А-534. Оп.1. Д.362.

18. ГАРФ. Ф.А-501. Оп.1. Д.6670.

19. ГАРФ. Ф.А-501. Оп.3. Д.1166.

20. ГАРФ. Ф.А-2307. ОП.14. Д.63.

21. Гниловской В. Г. Сталинский план преобразования природы и задачи краеведов Ставрополья // Материалы по изучению Ставропольского края. Вып. 1. Ставрополь: [б.и.], 1949. С.3-32.

22. Годунова Л. Н. Историко-революционные музеи в 1941-1982гг // Актуальные проблемы советского музееведения. Сб. науч. тр. / Центральный музей революции СССР. М. : [б.и.], 1987. С. 179-198.

23. Госданкер В. В. Непрошедшее время: субъективные записки старого музейщика. Ставрополь: Изд-во СГУ, 2009. 200с : ил.

24. Госданкер В. В. От прошлого нельзя отряхнуться (музейные поиски, находки, встречи). Ставрополь: Изд-во СгУ, 2005. $251 \mathrm{c}$.

25. Егоров Ю. С. Развитие музейной сети в условиях зрелого социализма (60-70-е гг.) // Музейное дело в СССР. Сб. науч. тр. М.: Центр. музей Революции СССР, 1985. С. 22-38.

26. Колесникова М. Е. Историко-краеведческая деятельность на Северном Кавказе в конце XVIII в - 20-30-е гг XX в. (По материалам Ставрополья): автореф. дис. ... канд. ист. наук. Ставрополь: СГУ, 1998. 25 С.

27. Колесникова М. Е. Изучение Северного Кавказа в России во второй половине XVIII - начале XХв.: диссертация ... докт. ист. наук. Ставрополь: СГУ, 2011. 921с.

28. Коротков С. Д. Музей «Домик Лермонтова» // Коммунар. 1933. 30 января. № 11. С. 4.

29. Лукаш М. А. Культурно-досуговая молодежная политика государства и ее реализация в Ставропольском крае в середине 60-х - 70-е гг. XX века: автореферат дис. ... кандидата ист. наук. Ставрополь, 2012. 29 с.

30. Музей и власть. Государственная политика в области музейного дела (XVIII-XX вв). Сб. науч. тр. / НИИ культуры). Ч.1. М.: НИИ культуры, 1991. 322с.

31. Попова Е. П. Роль музея в жизни многонационального региона (на материалах музеев Ставропольского края XIX-XX вв): автореф. дис. ... канд. ист. наук. М., 1993. 23 с.

32. Сафронова Л. П. Политико-массовая и культурная жизнь в Ставропольском крае в 1945-1964 годах: дис. ... канд. ист. наук. Пятигорск: ПГТУ, 2004. 151 с.

33. Ставропольский государственный музей-заповедник им. Г. Н. Прозрителева и Г. К. Праве (далее - СГМЗ). Ф. 4. Оп. 1. Д. 8.

34. СГМЗ. Ф. 4. Оп. 2. Д. 1.

35. Симкин М. П. Советские музеи в период Великой Отечественной войны // Труды НИИ музееведения. М.: [б.и.], 1961. Вып. II. С. 176-325.

\section{References}

1. Bagdasarjan A. A. Letopis' Pjatigorskogo kraevedcheskogo muzeja (1847-2005) (Chronicle of the Pyatigorsk Museum of Local Lore (1847-2005). Pyatigorsk: Vestnik Kavkaza, 2007. 202 p. (In Russian).

2. Bulygina T. A. Muzeinaya ekspozitsiya kak istochnik intellektual'noi istorii lokal'nogo soobshchestva (na primere SGMZ im. G.N. Prozriteleva i G.K. Prave) (Museum Exhibition as a Source of Intellectual History of the Local Community (by the Example of SSMR Named after G. N. Proziteleva and G. K. Prave) // Prozritelevskie chteniya: sbornik materialov nauchnoprakticheskoi konferentsii. Issue. 2 / ed by. S.N. Savenko. Stavropol' : Vestnik Kavkaza, 2006. P. 52-55. (In Russian).

3. State Archive of Contemporary History of Stavropol Krai (GANISK) . F. 1. Inv. 43. D. 2708. (In Russian)

4. GANISK. F. 1. Inv. 2. D. 580. (In Russian)

5. State archive of the Stavropol territory (GASK). F. R-164. Inv. 1. D. 484. (In Russian)

6. GASK. F. R-645. Inv. 3. D. 27. (In Russian)

7. GASK. F. R-645. Inv. 3. D. 112. (In Russian)

8. GASK. F. R-645. Inv. 3. D. 221. (In Russian)

9. GASK. F. R-645. Inv. 3. D. 394. (In Russian)

10. GASK. F. R-1077. Inv. 1. D. 33. (In Russian)

11. GASK. F. R-2174. Inv. 1. D. 38. (In Russian)

12. GASK. F. R-2928. Inv. 1. D. 10. (In Russian)

13. GASK. F. R-3020. Inv. 1. D. 37. (In Russian)

14. GASK. F. R-3798. Inv. 1. D. 221. (In Russian)

15. GASK. F. R-3798. Inv. 1. D. 1094. (In Russian)

16. GASK. F. R-4210. Inv. 1. D. 206. (In Russian)

17. State Archive of the Russian Federation (GARF). F. A-534. Inv. 1. D. 362. (In Russian)

18. GARF. F. A-501. Inv. 1. D. 6670 . (In Russian) 
19. GARF. F. A-501. Inv. 3. D. 1166. (In Russian)

20. GARF. F. A-2307. Inv. 14. D. 63. (In Russian)

21. Gnilovskoj V. G. Stalinskij plan preobrazovanija prirody i zadachi kraevedov Stavropol'ja (The Stalinist Plan to Transform Nature and Objectives of the Regional Specialists of Stavropol) // Materialy po izucheniju Stavropol'skogo kraja. Issue. 1. Stavropol', 1949. P.3-32. (In Russian)

22. Godunova L. N. Istoriko-revoljucionnye muzei v 1941-1982 gg (Historical-revolutionary Museums in 1941-1982) /I Aktual'nye problemy sovetskogo muzeevedenija. / Central'nyj muzej revoljucii SSSR. Moscow: Central Museum of Revolution of USSR, 1987. P. 179-198. (In Russian)

23. Gosdanker V. V. Neproshedshee vremya: sub)ektivnye zapiski starogo muzeishchika (The Past: the Subjective Notes of an Old Museum Worker). Stavropol': SSU publ., 2009. 200 p. (In Russian).

24. Gosdanker V. V. Ot proshlogo nel'zya otryakhnut'sya (muzeinye poiski, nakhodki, vstrechi) (It is Impossible to Reject the Past (Museum Searches, Findings, Meetings). Stavropol': SSU publ., 2005. 251 p. (In Russian).

25. Egorov Ju. S. Razvitie muzejnoj seti v uslovijah zrelogo socializma (60-70-e gg.) (Development of the Museum Network in the Conditions of Mature Socialism (the 60-70-ies.) // Muzejnoe delo v SSSR. Moscow, 1985. P. 22-38. (In Russian)

26. Kolesnikova M. E. Istoriko-kraevedcheskaja dejatel'nost' na Severnom Kavkaze v konce XVIII v-20-30-e gg XX v. (Po materialam Stavropol'ja) (Historical Local Operations in the North Caucasus in the Late Eighteenth Century - the 20-30-ies of $X X$ century (Based on materials of Stavropol territory): abstract of thesis. Stavropol', 1998. 25 p. (In Russian)

27. Kolesnikova M. E. Izuchenie Severnogo Kavkaza v Rossii vo vtoroj polovine XVIII - nachale XXV. (The study of the North Caucasus in Russia in second half XVIII - early XX century): thesis. Stavropol', 2011. 921 p. (In Russian)

28. Korotkov S. D. Muzej "Domik Lermontova" (Museum "The House Of Lermontov") // Kommunar. 1933. January 30. No 11. P. 4. (In Russian)

29. Lukash M. A. Kul'turno-dosugovaja molodezhnaja politika gosudarstva i ee realizacija v Stavropol'skom krae v seredine 60-h - 70-e gg. XX veka (Cultural and Leisure Youth Policy of the State and its / mplementation in the Stavropol Region in the mid-60s-70s of the Twentieth Century): abstract of thesis. Stavropol', 2012. 29 p. (In Russian)

30. Muzej i vlast'. Gosudarstvennaja politika v oblasti muzejnogo dela (XVIII-XX vv). (Museum and Power. State Policy in the Field of Museum Work (XVIII-XX Centuries). Part 1. Moscow, 1991. 322 p. (In Russian)

31. Popova E. P. Rol' muzeja v zhizni mnogonacional'nogo regiona (na materialah muzeev Stavropol'skogo kraja XIXXX vv.) (The Role of the Museum in the Life of a Multinational Region (on the Materials of Museums of Stavropol Region $X I X-X X$ centuries): abstract of thesis. Stavropol', 1993. (In Russian)

32. Safronova L. P. Politiko-massovaja i kul'turnaja zhizn' v Stavropol'skom krae v 1945-1964 godah (The Political Mass and Cultural Life in the Stavropol Krai in 1945-1964): thesis. Pyatigorsk: PSTU publ., 2004. (In Russian)

33. Stavropol State Museum Reserve named after G.N. Prozritelev and G.K. Prave. (SGMZ). F. 4. Inv. 1. D. 8. (In Russian)

34. SGMZ. F. 4. Inv. 2. D. 1. (In Russian)

35. Simkin M. P. Sovetskie muzei v period Velikoj Otechestvennoj vojny (Soviet Museums during the Great Patriotic War) // Trudy NII muzeevedenija. Moscow, 1961. Issue. II. P.176-325. (In Russian)

Сведения об авторе

Дугинец Светлана Михайловна - специалист по методической работе Ставропольского государственного медицинского университета (Ставрополь) / Bondarenko25@yandex.ru

Information about the author

Duginets Svetlana - Specialist in methodical work, Stavropol State Medical University (Stavropol) / Bondarenko25@yandex.ru 